\title{
Oedipus Complex in Literature Works
}

\author{
Yan Liu \\ School of Foreign Languages, Zhenjiang Watercraft University of PLA, Zhenjiang, China \\ Email: yaan.liu@gmail.com \\ Chencheng Wang \\ Zhenjiang Tiger Travel Service CO., LTD, Zhenjiang, China.
}

\begin{abstract}
In psychoanalytic theory, Oedipus complex denotes the emotions and ideas that the mind keeps in the unconscious, via dynamic repression, that concentrate upon a boy's desire to sexually possess his mother (Freud.1900). In the course of his psychosexual development, the complex is the boy's phallic stage formation of a discrete sexual identity; a girl's analogous experience is the Electra complex. Freud first mentioned the Oedipus complex in 1897. After his father's death, he began to make self-analysis, then the formation of the concept. The Interpretation of Dreams, published in 1900, it is the official presentation of the concept. Oedipus complex has always been a cornerstone of psychoanalytic theory. In classical, Freud's psychoanalytic theory, the child's identification with the same-sex parent is the successful resolution of the Oedipus complex and of the Electra complex; his and her key psychological experience to developing a mature sexual role and identity. Sigmund Freud further proposed that girls and boys resolved their complexes differently — he via castration anxiety, she via penis envy; and that unsuccessful resolutions might lead to neurosis, paedophilia, and homosexuality. Hence, men and women who are fixated in the Oedipal and Electra stages of their psychosexual development might be considered "mother-fixated" and "father-fixated" as revealed when the mate (sexual partner) resembles the mother or the father. This paper uses analysis and comparison method, through comparing the prototype of the Oedipus complex in Greek mythology, the similarities and differences between Oedipus King and the literatures contain the Oedipus complex--Hamlet, Sons and Lovers, Thunderstorm and $A$ Dream of Red Mansions. It discusses the main reason for the formation of their differences. It further reveals the Oedipus complex which impact on generations and promote the study of it.
\end{abstract}

Index Terms-Oedipus complex, psychoanalysis, literature comparison, son and moth

\section{INTRODUCTION}

Greek mythology--Oedipus King is about the story of Oedipus killed his father and marry his mother, which is the prototype of the Oedipus complex in psychology. The protagonist of the tragedy is the son of King Laius and Queen Jocasta of Thebes. After Laius learns from an oracle that he is doomed by the hand of his own son, he tightly binds the feet of the infant Oedipus together with a pin and orders Jocasta to kill the infant. Hesitant to do so, she orders a servant to commit the act for her. Instead, the servant takes baby Oedipus to a mountain top to die from exposure. A shepherd rescues the infant and names him Oedipus. The shepherd carries the baby with him to Corinth, where Oedipus is taken in and raised in the court of the childless King Polybus of Corinth as if he were his own. As a young man in Corinth, Oedipus hears a rumor that he is not the biological son of Polybus and his wife Merope. When Oedipus questions the King and Queen, they deny it, but, still suspicious, he asks the Delphic Oracle who his parents really are. The Oracle seems to ignore this question, telling him instead that he is destined to mate with his own mother, and shed with his own hands the blood of his own sire. Desperate to avoid his foretold fate, Oedipus leaves Corinth in the belief that Polybus and Merope are indeed his true parents and that, once away from them, he will never harm them.

On the road to Thebes, he meets Laius, his true father. Unaware of each other's identities, they quarrel over whose chariot has right-of-way. King Laius moves to strike the insolent youth with his sceptre, but Oedipus throws him down from the chariot and kills him, thus fulfilling part of the oracle's prophecy. He kills all but one of the other men. Shortly after, he solves the riddle of the Sphinx, which has baffled many a diviner: "What is the creature that walks on four legs in the morning, two legs at noon, and three in the evening?"(Freud,1900,P89--90)

To this Oedipus replies, "Man" (who crawls on all fours as an infant, walks upright later, and needs a walking stick in old age), and the distraught Sphinx throws herself off the cliffside. Oedipus' reward for freeing the kingdom of Thebes from her curse is the kingship and the hand of Queen Dowager Jocasta, his biological mother. The prophecy is thus fulfilled, although none of the main characters knows it.(Freud,1900,P91--92)

This complex works of literature in history repeated, Renaissance pinnacle of Shakespeare's Hamlet, published in 1913, Lawrence Sons and Lovers, the immortal in the history of Chinese literature work Dream of Red Mansions, Thunderstorm and so on.

\section{LITERATURE COMPARISON}


Shakespeare and his work make a tremendous impact on the world are almost household names to the world, and his work, Hamlet is not only a familiar name to us but also a summit.

In comparing and contrasting Oedipus and Hamlet, I see Oedipus as more of a man given to sudden, rash decisions and quick temper. Oedipus is definitely a man of action, where Hamlet stews over whether he should kill Claudius. Oedipus is a proud and selfless man, but is more concerned about his image than Hamlet. Hamlet is a very sensitive, moody person, very much in awe of his deceased father, who obviously didn't care about his image or he wouldn't have feigned "madness". Oedipus was a very passionate man, passionate about his position, his wife/mother, people of Thebes, and passionate about his concern for Polybus and Merope. Hamlet shows no genuine love for anyone except for his father and maybe his mother, but this is questionable because he would've killed his mother had the ghost instructed him to. Even when Hamlet declares his love for Ophelia, he later claims it's not true. He is, however, passionate about killing Claudius. Another contrast is that Hamlet is a thinker and a planner, where Oedipus is more emotional and wasn't patient enough to fully investigate the murder of Laius.

It is difficult to abandon the emotion to our mothers, a psychological fear of failure, afraiding to lose his mother, subsequently arise the antipathy to her. The result is the appearance of the personality of the beloved mother being affronted and ridicule. This complex, extremely abnormal behavior comes from Hamlet's subconscious. Similarly, the role of Oedipus in Oedipus King do these things is totally unconscious, it is precisely because of these "unconscious", it proves the existence of the Oedipus complex from the side. Who is initiative to love mother but hate father since the baby was born? How much of the psychological pressure he has to bear!

As Hamlet concentrated to the extreme, he is contradictory, his self-condemnation is punishing him, he even thought of life and death issues. This is the most famous passage of Hamlet:

To live or to die--that is a question. Whether it is nobler to merely suffer from the blow of doom or to fight against the troubles, and end them by opposing them. To die: it means to sleep and wake no more. And by it, we end the sufferings that are doomed in bodily life, which is a devoutly desired ending. (Shakespear, 1602,P110--111)

\section{B. The Similarities and Differences between Oedipus King and Sons and Lovers}

Sons and Lovers is British writer Lawrence's masterpiece of modernism. His novel also won a wide reputation. This novel has a strong autobiographical color. Make a nearby mining area of Nottingham as the background, around the coal miners Murray and his family. The growth process of young protagonist Paul reflects profound social problems and psychological problems. Paul's mother Gertrude and Paul's father married with falling-out, she turned to his son for love and comfort. This goes beyond the normal maternal feeling, then the feeling control and occupies the heart of his son; bring out the Freudian psychology to Paul, the "Oedipus complex" mentality. He loves his mother much more than any other women.

In the novel, we can see that Paul deeply loved his mother that he obeys what his mother said and did what his mother wished him to. During his life, all he did were to please his mother. When he was a child, he walked all day, went miles and miles to look for blackberries which his mother liked, rather than own himself beaten and came home to his mother's empty handed. When he was away from home, he looked forward to get home earlier because he knew that his mother was alone and waiting his back. In Paul's eyes, his mother was an elegant, undisturbed and beautiful young girl. Every night, he would send his mother to bed and kissed her for good night. After the death of his older brother, William, his family ran into a predicament. The expenditure of the family was larger and larger while the family lived with the wage of 26 ponds of the miner, his father. In order to help his mother to manage the household, Paul got a job in Nottingham and offered his mother his wages.

It was undutiful that Paul was a mourning son, but his main purpose was to help his mother. As to his father, he stood with his mother to be opposed to him, even he hated his father. When his father quarreled with his mother he even wanted to take the place of his father. He believed that his father mismatched his mother and there was no love in their marriage. Once he talked to Clara about love: "love is a dog in the mager"(D.H.Lawrence,1915, P56--57). The situation just liked his parents' marriage because even if his mother did not love his father anymore or hated him extremely, their marriage still continued and his mother would never leave his father. His words hinted to us that Paul had regarded his father as his rival of love; also we can see that Paul replaced his father and protest his mother. The love of the son and the mother was blameless, but it gradually developed into a kind of abnormal love, mother Fixation. We can get the evidence from the novel, once a time, after quarreling with her husband, Mrs. Morel despaired and complained to his son that she never had a husband, a true husband. After hearing this, Paul detested his father very much even he wanted to kill his father, at the same time, he deeply realized that his mother did not only nee d a good son but also a idea husband, and then he could not help touching the hair of his mother and kissing his mother's neck, of which was the strong evidence of Mother Fixation.

From many manifestations we can find that Paul and the original role of Oedipus King have a basic difference, the former one produced Oedipus complex while the woman is his biological mother but Oedipus didn't know the truth result in that he killed his father and marry his mother.

Whatever the meaning of Laius's oracle, the one delivered to Oedipus is clearly unconditional. Given our modern conception of fate and fatalism, readers of the play have a tendency to view Oedipus as a mere puppet controlled by greater forces, a man crushed by the gods and fate for no good reason (Wu Qiong,1994). This, however, is not an entirely accurate reading. While it is a mythological truism that oracles exist to be fulfilled, oracles do not cause the 
events that lead up to the outcome. In his landmark essay "On Misunderstanding the Oedipus complex", E.R. Dodds draws a comparison with Jesus's prophecy at the Last Supper that Peter would deny him three times. Jesus knows that Peter will do this, but readers would in no way suggest that Peter was a puppet of fate being forced to deny Christ. Free will and predestination are by no means mutually exclusive, and such is the case with Oedipus.

Although Mother Fixation was a sensitive subject in the literature world that people seldom refer to. It exists in the society as a common phenomenon that it has distorted the soul of mothers and sons, even damaged the family, which also obeys the ethics of human being. As to the author of Sons and Lovers, D. H. Lawrence, Mother Fixation made him so blind that he did not take care of the moral principles and did not know that he had come to the woman's family and left it broken. The novel Sons and Lovers also ended with a tragedy with the death of being mentally and physically exhausted of Mrs. Moreland the failure of Paul's love.

In our daily life, Mother Fixation is a common phenomenon, even if many people do not want to mention it or they do not accept the definition of Mother Fixation. The son who has Mother Fixation is lack of his own thoughts and enterprising spirit because he believes that his mother is his sanctuary and sunshine that never declines. Even when he gets married, his mother is the only person he can rely on not other person. So when there is conflict in his mother and wife he will stand with his mother, go against his wife. As to the mother who has Mother Fixation lavishes her lover upon her son, she controls his behavior and thoughts that she wishes that her son will never go against her. The son is her everything that she is afraid of losing him. As in China, most of the family conflict cause between the mothers and the daughters-in-law. One of the most important reasons is to fight for the domination of the husbands or sons. Once the daughters-in-law come to the family, the mothers will have a sense of tension that the daughters-in-law will take their place to love or control their sons that they are losing their sons. Gradually, the mothers will do something difficult for the daughters-in-law and say something to slander them before their sons, and then the family conflict arouses and the tragedy appears. In order to create a happy life and a harmonious society, we should pay our attention to Mother Fixation and deal with it well because Mother Fixation is a kind of abnormal human beings' love and we should pursue normal love.

\section{The Similarities and Differences between Oedipus King and Two Chinese Literary Works}

Having discussed the foreign literary masterpiece Oedipus King, now I want to study the similarities and differences between Oedipus king and two Chinese literary works--Thunderstorm and A Dream of Red Mansions.

In Thunderstorm, as ZhouPing in the zhou house, his concentrated aspect of missing content is love. The unconsciousness on Zhou Ping is more obvious, just for his incestuous behavior with his step-mother Fanyi. And after he loves Sifeng, without knowing her true identity, he is shameful to memorize his relationship with Fanyi. Therefore he is unwilling to remember it (Zhao Shankui, 2006). All of those are accorded to the definition of the unconsciousness that if one remembers the depressed emotion or experience, it will cause the excitement, the moral condemn, the shame and the fear of punishment. Zhou Ping's unwilling to remember it just for the moral principles, shame and the afraid of punishment. From what he says: "Eh? You mean you want me to stay here with you, in this god-forsaken place? So that everyday we've reminded of our past sins, until they gradually suffocate us? "We know that he is regretful and shameful, just like he says: "But surely you realize that such a relationship must a relationship must seem revolting to anyone else? ". (CaoYu, 1933, P66--69)

Oedipus is the same heroine as ZhouPing, they both hatred their father. Through the works we can imagine that, driven to the country by his father, didn't get much of love from his father. He hated his father, he once said to Fanyi: "I hope he die, even though I committed the immoral sin. (CaoYu,1933, P81)" This is a very obvious tendency of killing his father and marrying his mother. It is the strong indication of Oedipus complex.

Ancient Greek tragedy Oedipus King and Chinese modern tragedy Thunderstorm both have a kind of amazing artistic charm. The protagonists of these two scripts had maken efforts to avoid a tragedy, but eventually subjugated in the tragedy whirlpool. Either Oedipus king taken in the fate of force, or the ethical and moral strength power of Thunderstorm. They are played by the characters themselves to realize what is the tragic result, so all internal conflict or external contradictions should be embodied to the protagonists.

This two plays are highly similar in theme, structure and character design, but we all know that Thunderstorm absolutely is not taken simply reprinted by Oedipus King. In content, plot, background, there are real differences. Now, I only select characters design to make a simple comparison. We know, drama art appreciation should be appreciate a theatrical performance, not only refer to the script, but also a collective work of crystallization, characters, stage designer settings and so on. To theater work is only enjoy the show. But sino-foreign dramatic history legacy is mainly script instead stage art. So we can't feel the sino-foreign drama atmosphere discrimination from actor poise, gait and lines rhythm, temperament and differences only come from literature itself, tracing the internal character script.(Zhou Hua,2005)

One of "the collection books of contemporary aesthetic culture" home -- the parable of contemporary literary identity and gender, the author Li Jun illustrated the sinicization of Oedipus complex. He argued that the son - mother relationship is a performance of refusing to recognize the father value orders. On the contrary, the son identify the type of maternal value (for nature, human, home and so on). In this view, he pointed out that under the guidance of $A$ Dream of Red Mansions is actually the transformation and the fable metaphor of Chinese feudal society. Here, we see the notes to this rule. As a mother, Ms. Wang is naturally weak and insufficient to counter her husband on Jia Zheng's arbitrary 
and harsh. If only the mother is bound to be weak, however, the grandmother stood behind him. The feudal culture can make a strong enough shelter against the tyranny of Jia Zheng. This is a peculiar phenomenon of the feudal family. In front of his son and his wife, Jia Zheng is the absolute authority; but the face of grandmother, he became a very respectful son. It is this unique family's environment, so Baoyu is in front of his father formed a rebellious personality.

Of course, Baoyu in Dream of Red Mansions can only rebel against his father out along the dark. If the father of Jia Zheng is weaker and more loved to do of the grandmother, Baoyu would show greater rebellious spirit to his authoritarian father.

\section{CAUSES OF COMMONNESS}

\section{A. Psychological Explanation}

Oedipus complex is existed by the form of disguise plots in our lives. It not only affects a person's life, but also in art, pop music, literature, humor, insulting god, and many other sacred aspects. Like other elements of psychoanalytic theory, it suggests that there is a very general sense of the original existence of our body. (Freud,1900)The archetypal characters are frequently be observed in literature works, such as Oedipus King, Shakespeare's Hamlet, Paul in Sons and Lovers, and even though China's monumental masterpiece-- Zhouping of Thunderstorm and many characters in Dream of Red Mansions. Oedipus complex is due to the prevalence of psychological reasons. But for the majority, the concept that the moral context of them is an insult, they are not very easy to accept that feeling. Even if someone just hint to the "incest" for a litter, they would have been soon emerged a very strong aversion. Because of this reason, the theory of the Oedipus complex created a huge shock to many people and even it may be an excuse to reject all things related to psychoanalysis.

\section{B. The Background of the Literatures}

Father against to the son of Oedipus story is always the contradiction cannot be negated. If the type of Oedipus individual chose the discourse of father identity, it means giving up the primal recognition, growing to another generation of "father", then forcing to his filial parental discourse recognition. No matter how, the old story is a tragedy, an individual and maternal nature tragedy. Since human's existence, Oedipus story was constantly deduced. Therefore the above literature characters embodied fate.

For example, there are a number of similarities and differences between King Oedipus and Prince Hamlet. Both Hamlet and Oedipus are victims of fate, but Hamlet's father is murdered by his uncle Claudius while Oedipus kills his own father, if unwittingly. Hamlet and Oedipus can both avoid their fate, but each believes himself to be the only source of rectifying matters. Both Thebes and Denmark are in turmoil. Thebes is wracked by plague and other ills, while something is "rotten in the state of Denmark" . If there is anything that Hamlet and Oedipus share in common, it is their individual belief that it is up to them to save their respective states.(Fan Cunzhong,1983)

The cruel labor condition and living conditions under capitalist industrialization is the root cause of Paul's "Oedipus complex", and they break the happiness of the family, wrecked people's spiritual health development. (FanCunzhong, 1983) The capitalist industrialization make Murray into a working machine, depress and distort his humanity, instincts and destroys the harmonious relation between the husband and wife, father and son. At last it makes the love of Mrs.Murray abnormal. The Oedipus complex of Paul grows in his body.

Zhouping had grown up in loneliness and depression. He didn't return to Zhou house until 25 years old. Zhouping's father was busy with his coal mine all day, rarely went home. So as adolescence ZhouPing was eager to get bud warm love. Therefore, when young beautiful stepmother appeared, ZhouPing unconsciously fell in love with her.

Let's turn to the A Dream of Red Mansions. In traditional Chinese culture, father is often the absolute authority of mother who is difficult to resist tyranny to her son. As the highest authority in the family, grandmother gave Baoyu an effective asylum. She was the poweful mother of the family, appeased her son in the father's harsh rule by the psychological trauma, developed to correctly handle the relationship with his father, at the same time dared to be rebelliously against his father's personality.(Li Juan,2009)

The exploration of this theme in Oedipus King is paralleled by the examination of the conflict between the individual and the state in Antigone. The dilemma that Oedipus faces here is similar to that of the tyrannical Creon: each man has, as king, made a decision that his subjects question or disobey; each king also misconstrues both his own role as a sovereign and the role of the rebel. When informed by the blind prophet Tiresias that religious forces are against him, each king claims that the priest has been corrupted. It is here, however, that their similarities come to an end: while Creon, seeing the havoc he has wreaked, tries to amend his mistakes, Oedipus refuses to listen to anyone.

\section{CONCLUSION}

Roland. Bart said: "there is only one story, namely Oedipus story. (Guo Qunying, 2001)" All kinds of literary works in different text, conceal a story in the way of viewing, tell us the immensity of mother's happiness.

Tragedy comes in many forms, for example earthquakes, tornadoes and hurricanes are all types of tragedies. On the other hand, when talking about tragedy in literature, it has a whole different meaning. Tragedy in literature is on a 
smaller scale than things like earthquakes, tornadoes and hurricanes. In literature tragedy is usually about one person and the horrible things that happen to them during their life in a story or play.

In fact, some people know a little more should realize that the object of Freud study is mental patients. His research conclusion is worth referencing, but can not be the truth, because we are not neurotic, we shouldn't make the spontaneous problem.

But Freud said: "people should accept the facts that Greek myth reveals, like Oedipus accepts the inevitable fate "(Freud, 1900, P132).

Through the prototype of Oedipus complex Oedipus King, taken with the contrast of Hamlet, Sons and Lovers, Thunderstorm and A Dream of Red Mansions, we deeply understand the psychological crux. Oedipus complex as a human destiny symbol overall, is penetrated into each country each nation's history. No matter how it has changed could return to the original text.

\section{REFERENCES}

[1] Bernard Knox. (1994). Oedipus The King. Portland: Pocket Press.

[2] Cao Xueqin. (1784). A Dream of Red Mansions. Beijing: Foreign Languages Press.

[3] Caoyu. (1933).Thunderstorm. Beijing: Foreign Languages Press.

[4] D.H.Lawrence. (1915).Sons and Lovers. London: Penguin Books Ltd.

[5] Fan Cunzhong. (1983). History of English Literature. Chengdu: Sichuan People's Press.

[6] Freud. (1900).The Interpretation of Dreams. Ware: Wordsworth Editions Ltd.

[7] Guo Qunying. (2001). British Literature. Shanghai: Foreign Language Teaching and Education Press.

[8] Shakespear. (1602). Hamlet. Ware: Wordsworth Editions Ltd.

[9] WuQiong. (1994).Oedipus/reverse Oedipus complex -- and to a mass text interpretation of discourse. Journal of Chinese People's University,2,30-35.

[10] LiJuan. (2009). The Love and Sexual World of a Dream of Red Mansions and Taboos Against Incest. Ph.D. dissertation, University of Nanchang. http://cdmd.cnki.com.cn/Article/CDMD-11902-2010075838.htm (accessed 29/9/2010).

[11] ZhouHua. (2005). Read Oedipus Complex. Master dissertation, University of Sichuan. http://epub.cnki.net/grid2008/detail.aspx?dbname=CMFD9908\&filename=2005127186.nh (accessed 11/6/2010).

[12] ZhaoShankui. (2006). On the Subject and the Desire of the Oedipus Complex. Journal of School of Chinese Language and Culture Nanjing Normal University, 1, 17-21.

Yan Liu was born in Zhenjiang, China in 1979. She received her M.A degree in Social and Cultural Anthropology from Katholike Universiteit Leuven, Belgium in 2005.

She is currently an associate professor in the School of Foreign Languages, Zhenjiang Watercraft University of PLA, Zhenjiang, China. Her research interests include psycholinguistics and TESOL.

Chencheng Wang was born in Zhenjiang, China in 1988. She received her M.A degree in English from Jiangsu University, China in 2011.

She is currently an interpreter in Zhenjiang Tiger Travel Service CO.,LTD, Zhenjiang, China. Her research interests include psycholinguistics and American literature. 